\title{
Virulence, growth, and surface characteristics of Erwinia amylovora mutants with altered pathogenicity
}

\author{
Michel Tharaud, ${ }^{1}$ Mohammed Menggad, ${ }^{2}$ Jean Pierre Paulin ${ }^{3}$ and \\ Jacqueline Laurent ${ }^{2}$
}

Author for correspondence: Michel Tharaud. Tel: +3316412254 54. Fax: +331641731557.

\footnotetext{
1 ENITHP, Laboratoire de Pathologie Végétale, rue Le Nôtre, F-49045 Angers, France

2 Laboratoire de Pathologie Végétale, INRA, 16 rue

Claude Bernard, F-75231

Paris Cedex 05, France

3 Station de Pathologie Végétale, INRA,

Beaucouze, F-49070

Angers, France
}

\begin{abstract}
Erwinia amylovora CFBP1430 was mutagenized by phage MudIIPR13 insertion. Thirty prototrophic pathogenicity mutants with a single insertion were isolated. Among these, 17 non-pathogenic (Path ) mutants were obtained; 11 of them were unable to induce a hypersensitive response (HR) on tobacco (Hrp mutants), whereas the remaining six were still able to do so (Dsp mutants). Thirteen other mutants showed reduced virulence (Rvi ) and were still able to induce an HR. One of them appeared to be Path on apple seedlings and Rvi $\mathbf{~ o n ~}^{-}$ pear seedlings. All the Hrp mutants and all but three of the Dsp mutants mapped in the hrp-dsp gene cluster previously reported. Some Rvi ${ }^{-}$mutants also proved to map in this hrp-dsp region; most of them, as well as two Dsp mutants map in an unknown genomic region. Cell-surface components thought to play a role in bacterial pathogenicity were examined, including exopolysaccharides (EPS), lipopolysaccharides (LPS), and outer-membrane proteins. One mutant only was found to be non-capsulated and unable to produce EPS. The insertion in this mutant mapped in a genomic cluster involved in amylovoran synthesis. Unlike the parental strain, some mutants exhibited sensitivity to the phage $\mathrm{Ffm}$ and this phenotype was associated with a modified LPS electrophoretic profile. Rvi mutants and some Path mutants were able to multiply in planta to some extent; other Path mutants reached only a low population level, except the non-capsulated one, which rapidly decreased to an undetectable level.
\end{abstract}

Keywords: Erwinia amylovora, plant pathogen, virulence, cell-surface components

\section{INTRODUCTION}

Erwinia amylovora causes fire blight, a bacterial necrotic disease which affects all plant species of the section Pomoideae. The bacterium is destructive to pear and apple trees, as well as to a range of ornamentals including Crataegus, Cotoneaster and Pyracantha. On non-host plants (e.g. tobacco) E. amylovora elicits a typical hypersensitive reaction (HR). The pathogenesis of fire blight, though investigated over a number of years, is still largely unknown. Physiological and genetical studies have shown that extracellular polysaccharides (EPS) play a role in virulence (Bennett \& Billing, 1978; Steinberger \& Beer,

Abbreviations: DOC, sodium deoxycholate; EPS, exopolysaccharides; HR, hypersensitive reaction; OM-proteins, outer-membrane proteins; PCC, percentage of capsulated cells.
1988; Belleman \& Geider, 1992) but the existence of fully encapsulated avirulent strains suggested that at least one additional factor was essential for the expression of symptoms (Bennett, 1980; Steinberger \& Beer, 1988; Vanneste et al., 1990).

Molecular genetic tools have provided well-characterized pathogenicity mutants of E. amylovora, with single transposon insertions (Steinberger \& Beer, 1988; Barny et al., 1990; Walters et al., 1990; Bauer \& Beer, 1991). These insertions were localized, and most of them appeared to map in a gene cluster of approximately $40 \mathrm{~kb}$ on the chromosome. Several cosmids were isolated (Steinberger \& Beer, 1988; Barny et al., 1990; Walters et al., 1990; Bauer \& Beer, 1991), which were able to functionally complement these mutants. This large region was defined as an $b r p$ region, i.e. essential for both the elicitation of the HR on non-host plants and pathogenicity on host plants 
Table 1. Bacterial strains, bacteriophages and plasmids

\begin{tabular}{|c|c|c|}
\hline Strain or plasmid & Relevant characteristics & Source or reference \\
\hline \multicolumn{3}{|l|}{ Escherichia coli } \\
\hline ED8767 & supE supF bsdS rec $A 56$ met & Murray et al. (1977) \\
\hline \multicolumn{3}{|l|}{ Erwinia amylovora } \\
\hline CFBP1376 & Avirulent isolate from Cotoneaster $\mathrm{sp}$. & Paulin \& Samson (1973) \\
\hline CFBP1430 & Virulent isolate from Crataegus sp. & Paulin \& Samson (1973) \\
\hline PMV 6025 & $\mathrm{Rvi}^{-},::$MudIIPR $13, \mathrm{Cm}^{\mathrm{r}}$ & This work \\
\hline PMV6028 & $\mathrm{Dsp}^{-},::$MudIIPR13, $\mathrm{Cm}^{\mathrm{r}}$ & This work \\
\hline PMV6031, PMV6034, PMV6036, PMV6037 & $\mathrm{Rvi}^{-},::$MudIIPR13, $\mathrm{Cm}^{r}$ & This work \\
\hline PMV 6041 & $d s p-41::$ MudIIPR $13, \mathrm{Cm}^{\mathrm{r}}$ & Barny et al. (1990) \\
\hline PMV6046 & brp-46:: MudIIPR13, $\mathrm{Cm}^{\mathrm{r}}$ & Barny et al. (1990) \\
\hline PMV6047 & $\mathrm{Dsp}^{-},::$MudIIPR13, $\mathrm{Cm}^{\mathrm{r}}$ & This work \\
\hline PMV6067, PMV6068 & $\mathrm{Rvi}^{-},:$:MudIIPI $13, \mathrm{Cm}^{\mathrm{r}}$ & This work \\
\hline PMV6073 & brp-73:: MudIIPR13, $\mathrm{Cm}^{\mathrm{r}}$ & Barny et al. (1990) \\
\hline PMV6076 & $\Delta(b r p, d s p),::$ MudIIPR $13, \mathrm{Cm}^{\mathrm{r}}$ & Barny et al. (1990) \\
\hline PMV6081, PMV6082, PMV6086-PMV6088 & $\mathrm{Hrp}^{-},::$MudIIPR13, $\mathrm{Cm}^{\mathrm{r}}$ & \\
\hline PMV6089 & Dsp $^{-},::$MudIIPR13, $\mathrm{Cm}^{\mathrm{r}}$, non-capsulated & \\
\hline PMV6096, PMV6099 & Dsp $^{-},::$MudIIPR13, $\mathrm{Cm}^{\mathrm{r}}$ & \\
\hline PMV6100 & $\mathrm{Rvi}^{-},:$:MudIIPR $13, \mathrm{Cm}^{\mathrm{r}}$ & \\
\hline PMV6101, PMV6102 & $\mathrm{Hrp}^{-},::$MudIIPR13, $\mathrm{Cm}^{\mathrm{r}}$ & \\
\hline PMV6103, PMV6105 & $\mathrm{Rvi}^{-},::$MudIIPR13, $\mathrm{Cm}^{\mathrm{r}}$ & \\
\hline PMV6109 & $\mathrm{Hrp}^{-} .::$MudIIPR13, $\mathrm{Cm}^{\mathrm{r}}$ & This work \\
\hline PMV6110 & Rvi- $^{-},:$MudIIPR $13, \mathrm{Cm}^{\mathrm{r}}$ & \\
\hline PMV6112 & ${ }^{*} \mathrm{Rvi}^{-},::$MudIIPR13, $\mathrm{Cm}^{\mathrm{r}}$ & \\
\hline PMV6114 & $\mathrm{Hrp}^{-},::$MudIIPR13, $\mathrm{Cm}^{\mathrm{r}}$ & \\
\hline PMV6115 & Dsp ${ }^{-},:$:MudIIPR13, $\mathrm{Cm}^{\mathrm{r}}$ & \\
\hline PMV6116 & $\mathrm{Rvi}^{-}$, : : MudIIPR13, $\mathrm{Cm}^{\mathrm{r}}$ & \\
\hline PMV6117, PMV6119 & $\mathrm{Hrp}^{-},::$MudIIPR13, $\mathrm{Cm}^{\mathrm{r}}$ & \\
\hline \multicolumn{3}{|l|}{ Bacteriophages } \\
\hline $\operatorname{Br} 60$ & Lyses most rough mutants of Salmonella typhimurium & Wilkinson et al. (1972) \\
\hline $\mathrm{C} 21$ & Lyses mutants of E. coli and S. typhimurium & Lindberg (1973) \\
\hline Ffm & Lyses $r f a$ and $r f b$ mutants of Salmonella & Wilkinson et al. (1972) \\
\hline $\mathrm{P} 22$ & Mutant P22HT105 & Schmieger \& Backhaus (1973) \\
\hline PhiEC2 & & Résibois et al. (1984) \\
\hline Mu vir & Virulent mutant of $\mathrm{Mu}$ & \\
\hline \multicolumn{3}{|l|}{ Plasmids } \\
\hline pLA2917 & $\operatorname{oriT}(\mathrm{RK} 2), \cos (\lambda), \mathrm{Km}^{\mathrm{r}} \mathrm{Tc}^{\mathrm{r}}$ & Allen \& Hanson (1984) \\
\hline pPV130 & $\begin{array}{l}\text { pLA2 } 217 \text { with a } 32 \mathrm{~kb} \text { insert originating } \\
\text { from CFBP1430, } \mathrm{Tc}^{\mathrm{r}}\end{array}$ & Barny et al. (1990) \\
\hline pPV132 & $\begin{array}{l}\text { pLA2917 with a } 27 \mathrm{~kb} \text { insert originating } \\
\text { from CFBP1430, } \mathrm{Tc}^{\mathrm{r}}\end{array}$ & Barny et al. (1990) \\
\hline pPV133 & $\begin{array}{l}\text { pLA2917 with a } 31 \mathrm{~kb} \text { insert originating from } \\
\text { CFBP1430, Tc }\end{array}$ & Barny et al. (1990) \\
\hline pPV152 & $\begin{array}{l}\text { pLA2917 with a } 27 \mathrm{~kb} \text { insert originating } \\
\text { from CFBP143(), } \mathrm{Tc}^{\mathrm{r}}\end{array}$ & This work \\
\hline
\end{tabular}

* See Table 2.

(Steinberger \& Beer, 1988; Barny et al., 1990; Bauer \& Beer, 1991). Some mutations in a part of this large cluster induced a loss of pathogenicity but seemed not to be involved in the HR. Barny et al. (1990) considered this sub-region as being disease-specific ( $d s p$, designation proposed by Boucher et al., 1987, for genes involved in pathogenicity but no other phenotype); however, Bauer
\& Beer (1991) found that the mutants in this sub-region exhibit a loss of pathogenicity but an attenuation of their ability to induce the HR, so they did not clearly differentiate two separate clusters. Another group of pathogenicity mutants appeared to be deficient in EPS production (Steinberger \& Beer, 1988; Belleman \& Geider, 1992). Transposon insertions in some of these 
mutants mapped in a gene cluster of about $7 \mathrm{~kb}$ (Bernhard et al., 1993) required for both EPS production and pathogenicity. These genes were designated ams (Belleman \& Geider, 1992) for amylovoran synthesis (amylovoran is the main component of EPS from E. amylovora).

In this paper we present a further characterization of transposon-insertional mutants of E. amylovora, which share in common an alteration in pathogenicity. The features of mutants were chosen for their alleged or potential role in pathogenicity and/or in some step of the infection process: after a precise assessment of their residual pathogenicity (symptom expression on host plants, and HR on non-host plants), the mutants selected in this study were examined for properties associated with surface components (EPS, LPS), for in vitro and in planta growth rate, as well as for several physiological properties. The genomic localization of the corresponding mutations is also presented.

\section{METHODS}

Bacterial strains, plasmids, and culture conditions. Bacterial strains, bacteriophages and plasmids used in this study are listed in Table 1. E. amylovora strains were routinely grown at $25^{\circ} \mathrm{C}$ in either Luria broth (LB, Maniatis et al., 1982) or King's medium $\mathrm{B}$ (KB, King et al., 1954). Escherichia coli strains were grown in LB medium at $37^{\circ} \mathrm{C}$. Minimal media M63 or M9 (Miller, 1972) were supplemented with glucose as a carbon source $(0.2 \%)$ and nicotinic acid (0.02\%). YPA medium (Billing, 1984) supplemented with $\mathrm{D}$-galactose $(1 \%, \mathrm{w} / \mathrm{v})$ was used for the capsulation studies. Assimilation of 49 amino acids, 49 carbohydrates and 49 organic acids was studied by using the API system (LRA 50). Media were supplemented with antibiotics, when indicated, at the following concentrations $\left(\mu \mathrm{g} \mathrm{ml}^{-1}\right)$ : chloramphenicol $(\mathrm{Cm})$, 10 ; kanamycin $(\mathrm{Km}), 20$; tetracycline $(\mathrm{Tc}), 10$. For the screening of membrane mutants, LB or M63 agar medium was supplemented with either sodium deoxycholate (DOC, $1 \mathrm{mM}$ for $\mathrm{LB}+\mathrm{DOC}, 1.5 \mathrm{mM}$ for M63+DOC) or EDTA (400 mM for $\mathrm{LB}+\mathrm{EDTA}, 20 \mathrm{mM}$ for M63+EDTA). In vitro growth of the mutants was compared to the growth of the virulent parent strain CFBP1430. For this purpose, shaken cultures in $\mathrm{M} 9+$ glucose medium were sampled by plating at intervals during $24 \mathrm{~h}$.

Origin of E. amylovora mutants. E. amylovora CFBP1430 was mutagenized by phage MudIIPR13 insertion as described by Barny et al. (1990). Among the 5800 chloramphenicol resistant $\left(\mathrm{Cm}^{\mathrm{r}}\right)$ clones that were obtained, 49 appeared to be prototrophic, with a single transposon insertion and altered in pathogenicity. Out of these 49 mutants, 19 fully avirulent $\left(\mathrm{Path}^{-}\right)$ones have already been reported (Barny et al., 1990) although not thoroughly characterized by the criteria of the present study. The 30 other mutants were specially studied in the present work : in addition to $\mathrm{Path}^{-}$mutants they include mutants which were not completely avirulent $\left(\mathrm{Rvi}^{-}\right)$. On the basis of specific characteristics noticed in the course of this study, four mutants out of the 19 already described by Barny et al. (1990) are also described in more detail here. All techniques used for obtaining, selecting and characterizing the mutants were as described before (Barny et al., 1990).

Plant assays. The HR was tested on tobacco plants (Nicotiana tabacum L. cv 'Xanthi') infiltrated with a $10^{9}$ c.f.u. $\mathrm{ml}^{-1}$ bacterial suspension in sterile distilled water. Appearance of the HR was scored after incubation at room temperature for $24 \mathrm{~h}$. Patho- genicity tests on young (six to eight leaves) pear (Pyrus communis) and apple (open-pollinated 'Golden Delicious') seedlings were performed in the greenhouse as described previously (Laurent $e t$ al., 1987). Bacterial growth in planta was studied in the growth chamber. The youngest unfolded leaf of pear seedlings of 'Passe Crassane' (two to four leaves) was wounded by two parallel cuts through the midrib, and immediately inoculated with a drop of bacterial suspension $\left(3 \times 10^{6}\right.$ c.f.u. per leaf). At intervals $(3,8$, $24,48,72$ and $144 \mathrm{~h}$ ) five seedlings were separately crushed in $10 \mathrm{ml}$ phosphate buffer $(0 \cdot 2 \mathrm{M})$ and serial dilutions were plated on $\mathrm{KB}$ plates supplemented with chloramphenicol.

Serology. Bacteria were grown for $24 \mathrm{~h}$ on KB. The agglutination of the mutants in a specific antiserum was compared to that of the parental strain CFBP1430 by the slide agglutination test, using an antiserum raised against CFBP1430. Heat-killed bacteria $\left(100^{\circ} \mathrm{C}, 2 \mathrm{~h}\right)$ were used as antigens for the rabbit immunization (Samson, 1972). Control negative strains (Erwinia herbicola, E. carotovora, Pseudomonas sp.) were included in the test.

Capsulation. Bacterial cells were grown on YPA medium + galactose. The capsules were revealed by the wet India staining procedure of Duguid (1951). The percentage of capsulated cells (PCC) was determined using an interferencial phase-contrast microscope (Polyvar) and $100 \times$ magnification.

Sensitivity to bacteriophages. This was determined by spot assays, as described by Expert \& Toussaint (1985).

Extraction and analysis of LPS and OM-proteins. LPS was extracted from $E$. amylovora cells by using the miniscale procedure of Schoonejans et al. (1987). Samples were analysed for LPS by SDS-PAGE on $13.5 \%(\mathrm{w} / \mathrm{v}$ ) acrylamide gels, with silver-staining by the method of Hitchcock \& Brown (1983). OM-proteins were prepared and analysed by SDS-PAGE as described by Vanneste et al. (1990).

General DNA manipulations. Genomic DNA was isolated from E. amylovora cells by the method of Klötz \& Zimm (1972) and purified by $\mathrm{CsCl} /$ ethidium bromide density-gradient centrifugation. Plasmid DNA was isolated, and recombinant DNA was prepared and manipulated by using standard techniques (Maniatis et al., 1982). Introduction of plasmids into bacterial cells (by transformation or by mobilization), Southern blot analyses, and colony hybridization were performed as described by Barny et al. (1990).

\section{RESULTS}

\section{Pathogenicity of mutants}

Two classes of non-pathogenic $\left(\mathrm{Path}^{-}\right.$) mutants were obtained (Table 2): $\mathrm{Hrp}^{-}$mutants, which were no longer able to induce an $\mathrm{HR}$ in tobacco leaves, and Dsp ${ }^{-}$ mutants, which were still able to induce the HR. Seventeen (11 $\mathrm{Hrp}^{-}, 6 \mathrm{Dsp}^{-}$) prototrophic $\mathrm{Path}^{-}$mutants with a single MudIIPR13 insertion were obtained in addition to the $19 \mathrm{Path}^{-}\left(13 \mathrm{Hrp}^{-}, 6 \mathrm{Dsp}^{-}\right)$mutants already isolated by Barny et al. (1990).

Some mutants produced symptoms on host plants, but were less virulent than the parental strain CFBP1430 (fewer plants showed symptoms and the length of the stem necrosis was reduced); they were able to induce the HR. These less virulent mutants were designed Rvi-, for reduced virulence. Thirteen prototrophic $\mathrm{Rvi}^{-}$mutants, with a single MudIIPR13 insertion, were added to the Path $^{-}$mutants. The complete set of mutants studied is 
Table 2. Pathogenicity, mutated genomic region, and other studied characteristics of $E$. amylovora mutants

\begin{tabular}{|c|c|c|c|c|c|c|c|}
\hline Mutant & Pathogenicity* & $\mathbf{H R} \dagger$ & $\begin{array}{l}\text { Mutated } \\
\text { genomic } \\
\text { region } \ddagger\end{array}$ & $\begin{array}{l}\text { Growth } \\
\text { in vitro } \$\end{array}$ & $\begin{array}{c}\text { Growth } \\
\text { in planta\| }\end{array}$ & $\begin{array}{c}\text { Colony } \\
\text { morphology } \\
\text { on KBg }\end{array}$ & $\begin{array}{c}\text { Cell } \\
\text { capsulation\# }\end{array}$ \\
\hline PMV6081 & $\mathrm{Path}^{-}$ & - & $b r p$ & + & - & + & $=$ \\
\hline PMV6082 & Path $^{-}$ & - & $b r p$ & + & $+1-$ & + & $=$ \\
\hline PMV6086 & Path $^{-}$ & - & $b r p$ & + & - & + & $=$ \\
\hline PMV6087 & $\mathrm{Path}^{-}$ & - & $b r p$ & $+1-$ & - & + & $<$ \\
\hline PMV6088 & Path $^{-}$ & - & $b r p$ & + & - & + & $=$ \\
\hline PMV6101 & Path $^{-}$ & - & $b r p$ & + & $+/-$ & + & $=$ \\
\hline PMV6102 & Path $^{-}$ & - & brp & + & $+1-$ & + & $=$ \\
\hline PMV6109 & Path $^{-}$ & - & $b r p$ & + & - & + & $<$ \\
\hline PMV6114 & Path $^{-}$ & - & $b r p$ & + & $+1-$ & + & $<$ \\
\hline PMV6117 & $\mathrm{Path}^{-}$ & - & $b r p$ & + & $+1-$ & + & $=$ \\
\hline PMV6119 & $\mathrm{Path}^{-}$ & - & $b r p$ & + & - & + & $<$ \\
\hline PMV6028 & Path $^{-}$ & + & $\mathrm{u}^{\prime}$ & $+1-$ & ND & + & $=$ \\
\hline PMV6047 & Path $^{-}$ & + & $d s p$ & $+1-$ & - & + & $=$ \\
\hline PMV6089 & Path $^{-}$ & + & $a m s$ & + & 0 & - & 0 \\
\hline PMV6096 & Path $^{-}$ & + & $d s p$ & $+1-$ & - & + & $<$ \\
\hline PMV6099 & $\mathrm{Path}^{-}$ & + & $\mathrm{u}$ & + & $+1-$ & + & $=$ \\
\hline PMV6115 & $\mathrm{Path}^{-}$ & + & $d s p$ & $+1-$ & - & + & $<$ \\
\hline PMV6025 & $\mathrm{Rvi}^{-}$ & + & $u^{t}$ & + & ND & + & ND \\
\hline PMV6031 & $\mathrm{Rvi}^{-}$ & + & $\mathrm{u}$ & + & ND & + & $=$ \\
\hline PMV6034 & $\mathrm{Rvi}^{-}$ & + & $\mathrm{u}$ & + & ND & + & ND \\
\hline PMV6036 & $\mathrm{Rvi}^{-}$ & + & $\mathrm{u}$ & + & ND & + & ND \\
\hline PMV6037 & $\mathrm{Rvi}^{-}$ & + & $\mathrm{u}$ & + & ND & + & ND \\
\hline PMV6067 & $\mathrm{Rvi}^{-}$ & + & $b r p$ & + & + & + & $=$ \\
\hline PMV6068 & $\mathrm{Rvi}^{-}$ & + & $b r p$ & + & + & + & $=$ \\
\hline PMV6100 & $\mathrm{Rvi}^{-}$ & + & $\mathrm{ND}$ & + & + & + & $<$ \\
\hline PMV6103 & $\mathrm{Rvi}^{-}$ & + & $\mathrm{u}$ & $+1-$ & + & + & $>$ \\
\hline PMV6105 & $\mathrm{Rvi}^{-}$ & + & ND & $+1-$ & ND & + & $=$ \\
\hline PMV6110 & $\mathrm{Rvi}^{-}$ & + & $\mathrm{u}$ & + & + & + & $<$ \\
\hline PMV6112 & $* \mathrm{Rvi}^{-}$ & + & $d s p$ & + & + & + & $=$ \\
\hline PMV6116 & $\mathrm{Rvi}^{-}$ & + & $b r p$ & + & + & + & $=$ \\
\hline
\end{tabular}

ND, Not determined.

* Path ${ }^{-}$, non-pathogenic; $\mathrm{Rvi}^{-}$, reduced virulence on pear and apple seedlings; ${ }^{2} \mathrm{Rvi}^{-}$, reduced virulence on pear seedlings, non-pathogenic on apple seedlings.

† Hypersensitive reaction on tobacco plant: +, present; - , absent.

$\ddagger a m s, d s p, b r p$, see text; u, unknown, the insertion appeared not to be localized in the known regions ams, dsp, brp.

$\$$ Growth in vitro: + , identical to the parental strain; $+/-$, reduced as compared to the parental strain.

$\| 0$, mutant which failed to multiply and to survive; - , mutants which failed to multiply but were able to survive at low population level; $+/-$, mutants able to multiply but whose population did not regain the initial inoculum level; + , mutants able to multiply and to reach at best the initial inoculum level.

$\mathbf{I}+$, Smooth; - , rough.

\# Percentage of capsulated cells: > higher, = identical, < lower than that of the parental strain; 0 non-capsulated.

given in Table 2. One of the Rvi- mutants, PMV6112, exhibited a $\mathrm{Rvi}^{-}$phenotype on pear seedlings but a Path phenotype on apple 'Golden Delicious'.

\section{Physiological characteristics of the mutants}

Utilization of amino acids, carbohydrates and organic acids as sole source of carbon and energy. This was tested for 19 prototrophic mutants (belonging to the three defined classes $\left.\mathrm{Hrp}^{-}, \mathrm{Dsp}^{-}, \mathrm{Rvi}^{-}\right)$. No stable difference from the parental strain CFBP1430 was noticed (data not shown).

Bacterial growth in vitro. The results of in vitro bacterial growth studies are shown in Table 2. All the prototrophic mutants showed a growth curve identical to CFBP1430, with the exception of seven mutants which showed strongly reduced growth. In the latter mutants, the total 


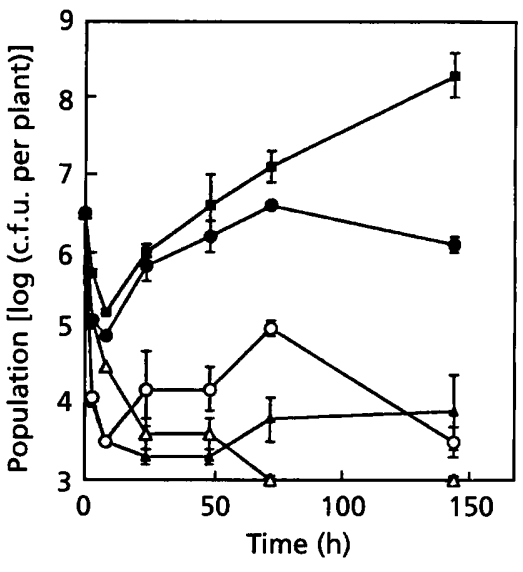

Fig. 1. Bacterial growth in planta of wild-type parental strain CFBP1430 and its mutants. Young pear seedlings were inoculated with $3 \times 10^{6}$ c.f.u. per leaf. At intervals, five seedlings were separately crushed and dilutions were plated on KB. Bars represent one standard error of the mean. $\square$, CFBP1430; $\triangle$. PMV6089; $\Delta$, PMV6086; O, PMV6114; O, PMV6116. Each mutant is representative of a type of growth (see Table 2).

or partial loss of pathogenicity, together with the reduced growth in vitro, might be due to an alteration in genes involved in housekeeping functions.

Bacterial growth in planta. The typical growth of mutants on pear seedlings is shown in Fig. 1. During the first $8 \mathrm{~h}$ after inoculation, the population level of all strains decreased. Six days $(144 \mathrm{~h})$ after inoculation, the wild-type strain CFBP1430 had multiplied to reach about $10^{8}$ c.f.u. per plant (Fig. 1), while $\mathrm{Path}^{-}$mutants showed three types of growth (Fig. 1, Table 2): (i) one mutant (PMV6089) failed to multiply and its concentration decreased to an undetectable level (less than $10^{3}$ c.f.u. per plant) within $72 \mathrm{~h}$; (ii) nine mutants represented by PMV6086 in Fig. 1, did not multiply, but their population level remained fairly stable, at a low level (about $10^{4}$ c.f.u. per plant) during the $144 \mathrm{~h}$ of the experiment; (iii) six mutants, represented by PMV6114, were able to multiply for 48-72 h after inoculation and reached about $10^{5}$ c.f.u. per plant, then their population level decreased sharply; in no case did their population regain the initial inoculum level. On the other hand, the $\mathrm{Rvi}^{-}$mutants, represented by PMV6116, multiplied in planta and were able to reach at best the population levels of the initial inoculum (Fig. 1, Table 2).

\section{Cell-surface characteristics of the mutants}

The following approaches were used to determine whether some of our mutants were modified in their surface characteristics.

Serology. With suitable dilutions of the antiserum, the parental strain CFBP1430 was slide-agglutinated within 2-3 min. In the same conditions the mutant PMV6089 was agglutinated within $30 \mathrm{~s}$; the other mutants were agglutinated after more than $3 \mathrm{~min}$ only. Cells of the naturally avirulent CFBP1376 were agglutinated in the same time scale as CFBP1430. Agglutination was never observed with the other Erwinia spp. and Pseudomonas sp. tested.

Colony morphology and cell capsulation. When grown on KB, all tested mutants but one (PMV6089) showed a smooth colony type (Table 2), indicating the production of EPS (Sijam et al., 1983). PMV6089 gave rise to rough colonies. All smooth-type mutants showed a much more fluidal colony morphology than the parental strain CFBP1430. The naturally non-pathogenic strain CFBP1376 had the same colony type as CFBP1430. At least 400 cells of each mutant were observed under the microscope to determine the percentage of capsulated cells (PCC). This PCC was compared to the PCC of CFBP1430, grown in the same conditions (Table 2). Mutant PMV6089 was not capsulated. Most of the other tested mutants (16 out of 26 ) showed, like CFBP1430, a PCC of 12-15; eight mutants exhibited a lower PCC than CFBP1430 (1-5); one mutant (PMV6103) had a greater PCC than the parental strain (70).

Phage sensitivity and characteristics of the LPS. Some surface properties of the mutants were examined through their phage susceptibility. Phages used in this test are given in Table 1. None of the tested mutants appeared different from the parental strain CFBP1430, except for the reaction to phage $F f m$ (Table 3). The virulent phage Ffm infects Escherichia coli $\mathrm{K} 12$ and most rough mutants of Salmonella typhimurium or Erwinia chrysantbemi (Wilkinson et al., 1972; E. D. Schoonejans, personal communication). For the two latter bacterial species phage $\mathrm{Ffm}$ appears to specifically attach to the core of LPS. Therefore, PAGE of the LPS from the Ffm sensitive mutants was performed.

The LPS from strain CFBP1430 showed a low molecular mass material corresponding to the core part, and a higher molecular mass heterogeneous material showing a ladder of equidistant bands representing the side-chain, an $\mathrm{O}-$ antigen-like structure. Similar profiles were observed for the LPS of mutants which were resistant to phage $\mathrm{Ffm}$. All the LPS profiles from mutants sensitive to phage $\mathrm{Ffm}$ were modified (Fig. 2). For two mutants, PMV6028 and PMV6041, the side-chain appeared displaced towards lower molecular masses and there was a decrease in the number of bands. For the other $\mathrm{Ffm}$-sensitive mutants, PMV6101, PMV6102 and PMV6112, there was no (or very little) side-chain material. The amount of side-chain material relative to the core part of LPS appeared to be lower in PMV6101 and PMV6102 than in PMV6112.

OM-proteins. DOC as detergent, and EDTA as chelator of divalent cations, are known to interfere with outermembrane stability. For instance EDTA weakens LPSLPS interactions and causes the release of LPS and proteins in the form of a LPS-protein complex (Gilleland, 1977; Nikaido \& Vaara, 1985). It has also been shown that resistance to bacteriocins, corresponding to the loss or alteration of an OM-protein, sometimes results in increased sensitivity to detergents and chelating agents 
Table 3. Characteristics of $E$. amylovora mutants exhibiting altered surface features

\begin{tabular}{|c|c|c|c|c|c|c|c|c|}
\hline \multirow[t]{2}{*}{ Strain } & \multirow{2}{*}{$\begin{array}{l}\text { Aspect of } \\
\text { the colonies } \\
\text { on L-agar }\end{array}$} & \multirow{2}{*}{$\begin{array}{c}\text { Pathogenicity } \\
\text { and } \\
\text { mapping }\end{array}$} & \multirow{2}{*}{$\begin{array}{c}\text { Sensitivity } \\
\text { to phage } \\
\text { Ffm* }\end{array}$} & \multirow{2}{*}{$\begin{array}{c}\text { LPS } \\
\text { profile } †\end{array}$} & \multicolumn{4}{|c|}{ Growth $\ddagger$ on: } \\
\hline & & & & & $\mathbf{L B}+\mathrm{DOC}$ & $\mathbf{L B}+\mathbf{E D T A}$ & M63 + DOC & M63 + EDTA \\
\hline CFBP1430 & Mucoid (+) & + & $\mathrm{R}$ & $t$ & + & + & + & + \\
\hline PMV6028 & $\begin{array}{l}\text { Slow growth } \\
\text { rough }\end{array}$ & $\mathrm{Dsp}^{-}$? & S & $M$ & As on L-agar & +++ & Very poor $g r$ & owth on M63 \\
\hline PMV6076 & + & $\mathrm{Hrp}^{-} \Delta b r p-b r m$ & $\mathrm{R}$ & M & + & $+($ rough $)$ & - & - \\
\hline PMV6041 & Rough & $\mathrm{Dsp}^{-}$hrm & $\mathrm{S}$ & M & + & + & - & - \\
\hline PMV6047 & + & $\mathrm{Dsp}^{-} \mathrm{brm}$ & $\mathrm{R}$ & -- & + & + & $+1-$ & + \\
\hline PMV6101 & + & $\mathrm{Hrp}^{-} \Delta h r m$ & $\mathrm{~S}$ & M & $+($ rough $)$ & $+($ rough $)$ & - & - \\
\hline PMV6102 & + & $\mathrm{Hrp}^{-} \Delta b r m$ & S & M & $+($ rough $)$ & $+($ rough $)$ & - & - \\
\hline PMV6112 & + & $\mathrm{Dsp}^{-}$hrm & $\mathrm{S}$ & M & $\begin{array}{c}+ \\
\text { (more mucoid) }\end{array}$ & + & - & - \\
\hline PMV6089 & $\begin{array}{l}\text { Rough } \\
\text { acapsular }\end{array}$ & $\mathrm{Dsp}^{-} a m s$ & $\mathrm{R}$ & + & $+($ rough $)$ & $+($ rough $)$ & + & - \\
\hline
\end{tabular}

* $\mathrm{R}$, resistant; $\mathrm{S}$, sensitive.

$\dagger+$, normal; $M$, modified.

$\ddagger$ Growth was tested on the agar media indicated. + , Growth as CFBP1430; + + +, better growth than CFBP1430; + / - less growth than CFBP1430; - , no growth.

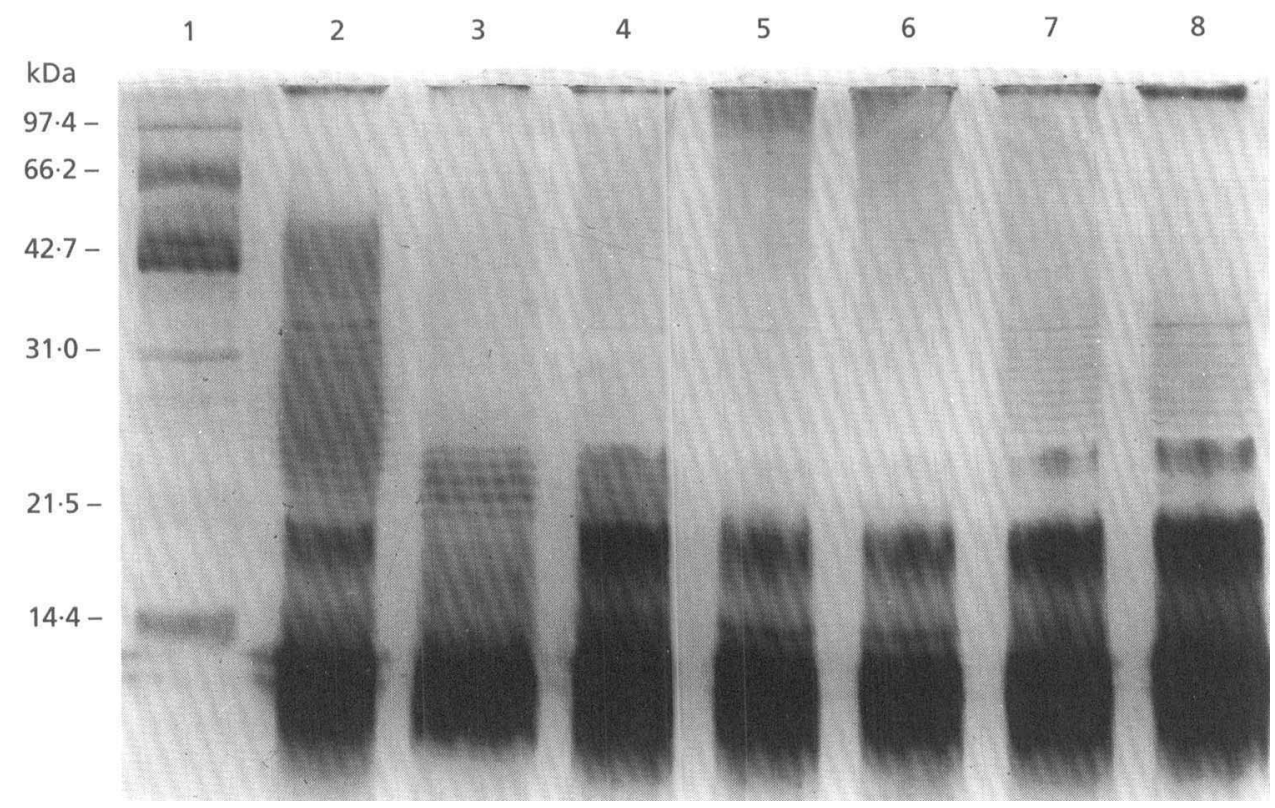

Fig. 2. LPS profiles of CFBP1430 and $\mathrm{Ffm}^{\mathrm{S}}$ mutants of $E$. amylovora. LPS was obtained by the miniscale procedure and samples were analysed by silver-stained SDS-PAGE (13.5\% acrylamide). Lane 1, standard proteins (Bio-Rad), from top to bottom: phosphorylase $b$, bovine serum albumin, ovalbumin, carbonic anhydrase, soybean trypsin inhibitor, and lysozyme. Lanes 2-8, LPS from CFBP1430 (5 $\mu \mathrm{l})$, PMV6028 (5 $\mu \mathrm{l})$, PMV6041 (5 $\mu \mathrm{l})$, PMV6101 (5 $\mu \mathrm{l})$, PMV6102 (5 $\mu \mathrm{l})$, PMV6112 $(4 \mu \mathrm{l})$, PMV6112 $(8 \mu \mathrm{l})$, respectively.

(Expert \& Toussaint, 1985). Thus the 49 pathogenicity mutants of $E$. amylovora, either $\mathrm{Path}^{-}$or $\mathrm{Rvi}^{-}$, were screened for sensitivity to DOC or EDTA, either on LB agar medium or on M63 agar medium as described in Methods. Eight clones exhibited a modified sensitivity when compared to CFBP1430 (Table 3). The OMproteins from these mutants were analysed: no obvious difference was observed between the electrophoretic profiles of the OM-proteins from the mutants as compared to CFBP1430 (data not shown). Thus, the mutations 
responsible for modified sensitivity to DOC and/or EDTA might affect a minor protein not easily detectable under the condtiions used. Alternatively the effects of DOC and EDTA on the mutants studied might not be OM-protein specific and should be correlated to modifications in other outer-membrane components, especially LPS.

\section{Localization of the MudIIPR13 insertions in a previously cloned chromosomal DNA region}

We looked for MudIIPR13 insertions in the $b r p-d s p$ region of the genomic DNA from the pathogenicity mutants. Three overlapping cosmids, pPV130, pPV132 and pPV133 (Table 1), covering the entire region considered, were used as probes for Southern blot hybridization with genomic DNA digests from each mutant.

The insertion in every $\mathrm{Hrp}^{-}$mutant appeared to be localized in this region (Fig. 3). In addition to the Hrp mutant PMV6076, three Hrp mutants showed a deletion in this region. In PMV6082 the entire region (about $52 \mathrm{~kb}$ ) was deleted, as it was in PMV6076. The deletion in PMV6101 and PMV6102 was smaller (about $11 \mathrm{~kb}$ ) and involved the $d s p$ subregion (Barny et al., 1990). The MudIIPR13 insertions in three additional Dsp ${ }^{-}$mutants (PMV6047, PMV6096, PMV6115) proved to map in this subregion.

For all but four of the $\mathrm{Rvi}^{-}$mutants, and for three $\mathrm{Dsp}^{-}$ mutants (PMV6028, PMV6089, PMV6099), the insertions did not map in the above-mentioned region. The insertions in three $\mathrm{Rvi}^{-}$mutants (PMV6067, PMV6068 and PMV6116) mapped in the $b r p-d s p$ region. The insertion of PMV6112, which was $\mathrm{HR}^{+}$on tobacco leaves, $\mathrm{Path}^{-}$on apple shoots and $\mathrm{Rvi}^{-}$on pear shoots (Table 2), was localized at the left-end limit of the $3.9 \mathrm{~kb}$ Sall fragment (Fig. 3).

\section{Cloning of the genomic DNA mutagenized in the acapsular mutant PMV6089 and search for other insertions in the same region}

Total DNA from the acapsular mutant PMV6089 was digested to completion with $\mathrm{Bg} / \mathrm{II}$ and fractionated in a sucrose gradient. The fragments sizing at about $20 \mathrm{~kb}$ were ligated to the cosmid pLA2917 previously linearized with the same enzyme. The ligation mixture was packaged in the presence of $\lambda$ phage encapsidation extracts and introduced into Escherichia coli ED8767 cells, selecting for resistance to both chloramphenicol and tetracycline.

A $B g l$ II-HindIII fragment was isolated from the PMV6089 insertion. This BglII-HindIII fragment was ${ }^{32}$ P-labelled and used as a probe to screen a pLA2917 genomic library from CFBP1430 (Barny et al., 1990). Five clones hybridized with the probe: as deduced from its physical map, the corresponding CFBP1430 genomic region was different from the brp area (Fig. 4). The physical map of the E. amylovora insertion in the cosmid pPV152 was compared with that of the plasmid pEA109

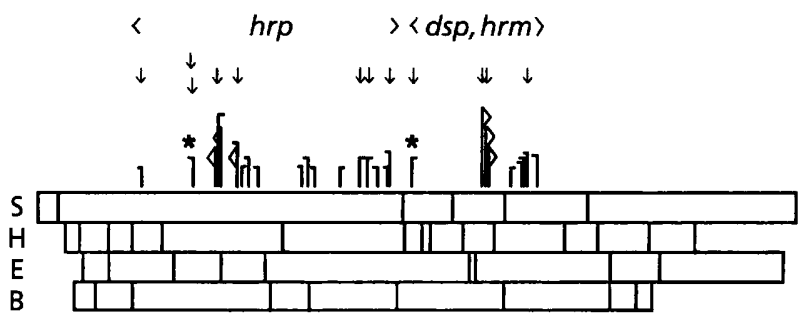

$10 \mathrm{~kb}$

Fig. 3. Location of MudIIPR13 insertions in the hrp gene cluster of $E$. amylovora. The restriction enzyme map shows the sites for S, Sall; H, HindIII; E, EcoRI; and B, BamHI. The locations of MudIIPR13 insertions are indicated above the physical map. Seventeen insertions were previously mapped; the names of the corresponding mutants are given in Barny et al. (1990). The insertions that were not previously mapped are highlighted by a vertical arrow; from left to right (in square brackets are mutations which could not be precisely localized in the indicated area and are not represented on the map) they are: PMV6117, [PMV6109], PMV6067 and PMV6068, PMV6086, PMV6088, [PMV6087, PMV6116], PMV6114, PMV6081, PMV6119, PMV6112, PMV6115, PMV6096, and PMV6047. The directions of the insertions are indicated by the directions of the pointers $(1)$ or of the flags $(P)$. Flags indicate insertions which could be used to monitor gene expression via $\beta$ galactosidase activity (Barny et al., 1990; M.-A. Barny \& J. Laurent, unpublished data); pointers indicate insertions which could not be used for that purpose. The asterisks (*) correspond to $\mathrm{Rvi}^{-}$mutants. The deletion mutants are not represented: PMV6082 spans the whole region as previously shown for PMV6076 (Barny et al., 1990); the deletions in PMV6101 and PMV6102 are restricted to the $d s p-h r m$ sub-area.

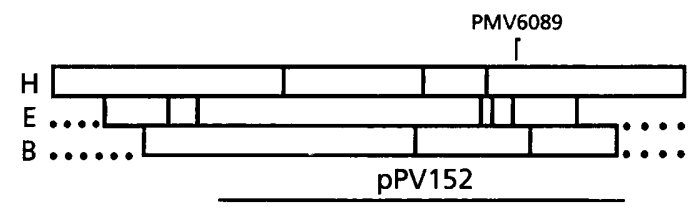

$10 \mathrm{~kb}$

Fig. 4. Location of a MudIIPR13 insertion in an ams gene cluster of $E$. amylovora. The restriction enzyme map shows the sites for $\mathrm{H}$, HindIII; E, EcoRI; and B, BamHI. The location of the MudIIPR13 insertion in PMV6089 is indicated above the physical map. The direction of the pointer $(I)$ indicates the direction of the insertion. Extension of the insert present in pPV152 is indicated by the horizontal line (bottom).

obtained by others (Bellemann \& Geider, 1992; Bernhard et al., 1993) and covering a large genomic cluster involved in amylovoran synthesis (ams genes). Part of both plasmid maps appeared similar and hybridization experiments proved that they shared homology (data not shown). This region has been studied in detail by M. Menggad (unpublished). The cosmids pPV151 and pPV152, covering a large part of this region, were mobilized into PMV6089 cells. As a control pLA2917 was also mobilized into PMV6089 cells. The resulting transconjugants were 
assayed for pathogenicity on pear and apple seedlings. The transconjugants harbouring pPV151 or PPV152 were able to restore typical fire blight symptoms while those harbouring pLA2917 were not, indicating that the loss of pathogenicity was due to the MudIIPR13 insertion in the chromosome of strain PMV6089.

The cosmid pPV152 was used as a probe for Southern blot hybridization with genomic DNA digests from each pathogenicity mutant. None of the mutations appeared to map in the same genomic region as the insertion in PMV6089.

\section{DISCUSSION}

This study of insertional mutants of E. amylovora focused on pathogenicity, growth in vitro and in planta, and some membrane characteristics. After mutagenesis with MudIIPR13, stable potential pathogenicity mutants of $E$. amylovora were selected as having lost the ability to induce exudate formation on apple calli according to Paulin \& Duron (1986) $\left(\mathrm{Cal}^{-}\right.$mutants, as opposed to $\mathrm{Cal}^{+}$, which are able to do so). Thirty prototrophic pathogenicity mutants with a single MudIIPR13 insertion were identified. Thirteen $\mathrm{Rvi}^{-}$mutants showed reduced virulence in planta, and $17 \mathrm{Path}^{-}$mutants were avirulent on susceptible hosts. Among the Path ${ }^{-}$mutants, $11 \mathrm{Hrp}^{-}$mutants were no longer able to induce HR in tobacco whereas six Dsp ${ }^{-}$ mutants were. All the $\mathrm{Hrp}^{-}$mutants map in the large brp gene cluster previously reported (Steinberger \& Beer, 1988; Barny et al., 1990; Bauer \& Beer, 1991). Most Dspmutants map in a sub-area of this large gene cluster that we previously defined as a $d s p$ region (Barny et al., 1990). Since Wei et al. (1992a) mentioned that mutants in the socalled $d s p$ area showed a variable Hrp phenotype, and since we found that a deletion in this region (PMV6101, PMV6102) produced a clear-cut $\mathrm{Hrp}^{-}$phenotype, we propose to consider this genomic region as a $\mathrm{hrm}$ (hypersensitive response modulator: Huang et al., 1991) region rather than a $d s p$ one, although the observed phenotypes are not exactly similar to those described by these authors for Pseudomonas syringae pv. syringae 61. The discrepancy between the observations of Wei et al. (1992a) and our results might be due mainly to different experimental conditions, particularly the size of inoculum used in tobacco plant inoculation, which was higher in our experiments. However, since we did not obtain any other mutant with an insertion localized in the approximately $4 \mathrm{~kb}$ space between the location of the insertions in PMV6112 and in PMV6115, we have no indication of the phenotype that would be shown by such a mutant. Some $\mathrm{Rvi}^{-}$mutants at least, PMV6067, PMV6068, PMV6112 and PMV6116, also proved to map in the $b r p$ region. These data suggest that, in these mutants, the insertion is near the end of a gene with the resulting gene product shorter than the normal gene product, thus exhibiting a lower efficiency than the normal one. A similar alteration in the gene product might also explain the $\mathrm{Rvi}^{-}$phenotype of PMV6112 on pear seedlings. The difference in virulence of PMV6112 on apple and pear seedlings might be due to a higher resistance level in our apple seedlings than in our pear seedlings. In the hypothesis of an interaction between a bacterial and host product, the altered bacterial product in PMV6112 might still be capable of some interaction with a pear product, while unable to interact with an apple one. Interestingly PMV6112 seems to be located in the $b r p N$ locus described by Wei et al. (1992b). Further studies are currently in progress to elucidate the different behaviour of this mutant on apple and pear and the role of the $\operatorname{brp} N$ product in E. amylovora.

The reason why only one mutant without a capsule was found in this study is not known. It is noteworthy that among 49 pathogenicity mutants, either $\mathrm{Path}^{-}$or $\mathrm{Rvi}^{-}$, we found only one EPS ${ }^{-}$mutant, while others (Steinberger \& Beer, 1988; Belleman \& Geider, 1992) found far more EPS ${ }^{-}$mutants as compared to other pathogenicity mutants. Both groups used $\operatorname{Tn} 5$ insertion mutagenesis, with different parental strains. Our parental strain CFBP1430 appears much more fluidal than those of the other workers. It might have genetic characteristics such as gene duplication so that an EPS ${ }^{-}$phenotype would rarely appear. Alternatively, although MudIIPR13 and Tn 5 are supposed to insert randomly into the target genome, they might have preferential insertional sites so that the Mu derivative would rarely be inserted into EPSencoding genes of E. amylovora.

Thus most $\mathrm{Path}^{-}$mutations map in already known genomic regions. However, two Dsp ${ }^{-}$(PMV6028 and PMV6099) and most $\mathrm{Rvi}^{-}$mutations do not map either in the $b r p-d s p$, or in the ams cluster. It was also shown that none of the corresponding insertions was in the ubiquitous plasmid pEA28 (Falkenstein et al., 1988; Laurent $e t$ al., 1989) of E. amylovora (data not shown). At least for $D_{s p}^{-}$mutants this is consistent with the fact that $E$. amylovora strains which are cured of this plasmid are still able to induce fire blight symptoms on host plants (Laurent et al., 1989; Falkenstein et al., 1989). Because at least three restriction enzymes, BamHI, EcoRI and HindIII, were used for the localization experiments, it is possible that pathogenicity genes might be located in other genomic regions. To identify the affected genomic region in these mutants, it would be necessary to clone the border of the transposon insertion. Since PMV6028 and PMV6099 show different growth and surface characteristics their mutated genes should govern different functions.

Some pathogenicity mutants exhibit sensitivity to the phage $\mathrm{Ffm}$. This phenotype is associated with a modified LPS electrophoretic profile. Two types of modifications were observed: PMV6101, PMV6102 and PMV6112 had no or very few large LPS molecules with normal sidechain length, while PMV6028 and PMV6041 showed mainly molecules with short side-chains. Several clones from our collection of insertional mutants were screened for sensitivity to the phage Ffm. It is noteworthy that nine $\mathrm{Cal}^{-}$mutants (unable to induce exudate formation on apple calli) out of 70 were $\mathrm{Ffm}^{\mathrm{s}}$, whereas no $\mathrm{Ffm}^{\mathrm{S}}$ clone was found among $100 \mathrm{Cal}^{+}$clones (data not shown). This might reflect a relation between the $\mathrm{Cal}^{-}$phenotype and a modified LPS content, composition, and/or structure. 
However, the $\mathrm{Cal}^{-} \mathrm{Ffm}^{\mathrm{S}}$ mutants showed diverse pathogenicity phenotypes, including full virulence. Thus there was no direct relationship between a modified LPS and pathogenicity. Two Dsp ${ }^{-}$mutants, PMV6079, with a normal LPS profile (data not shown), and PMV6041, with a modified LPS profile, map very close to each other. This indicates that the LPS defect in PMV6041, which is not restored by the cosmid pPV132 (M.-A. Barny, personal communication), might be due to a spontaneous mutation in a genomic region different from the $b r p$ gene cluster. The cloning and mapping of the mutation in PMV6028, as well as complementation assays with a cosmid harbouring the wild-type corresponding region, should help to test this hypothesis.

The three mutants (PMV6101, PMV6102, PMV6112) which exhibit the other type of modified LPS profile map in the $\mathrm{brm}$ sub-area of the large $b r p$ gene cluster. Since there is a deficit of side-chain material in the LPS of these mutants, which include two deletion mutants, one can postulate that at least one gene in the deleted fragment has regulatory functions on LPS biosynthetic genes. Alternatively, one of these $\mathrm{hrm}$ genes at least encodes an outermembrane component so that the outer membrane of the mutants PMV6101, PMV6102 and PMV6112 might have an altered structure, thus preventing the large LPS molecules with long side-chains remaining tightly attached to the membrane. It is worth pointing out that the mutant PMV6028, with the other modified LPS profile, shows in addition a specific EDTA-dependent phenotype suggesting an altered membrane structure. Since the mutants showing a modified LPS profile are agglutinated in the CFBP1430-specific antiserum, one might assume that the corresponding antigenic sites are conserved. Taken together these data suggest that several outermembrane components, in relation with LPS molecules, are involved in plant-bacteria interactions.

The presence of a capsule around bacterial cells was another approach to determine whether our mutants were altered in their surface characteristics, as compared to the parental strain CFBP1430. One mutant (PMV6089) appeared to be non-capsulated, and unable to produce EPS, even if grown on YPA medium supplemented with Dgalactose, which is known to stimulate capsule synthesis (Billing, 1984). Most of the other mutants studied exhibited a PCC similar to, or lower than that of CFBP1430; their colony morphology was smooth but much more fluidal than that of CFBP1430. The mutation in PMV6103, which led to a higher PCC, might affect a gene encoding a repressor of capsular polysaccharide biosynthesis. Since there is no correlation (with the exception of PMV6089) between PCC and colony morphology, one cannot infer from our results that regulators of EPS biosynthesis such as rcs-like or lon-like genes were altered in our mutants (for reviews see Coplin \& Cook, 1990; Roberts \& Coleman, 1991).

The slide agglutination test used, though simple, gave interesting results because it applies to somatic-O antigens (Samson, 1972). With this method all mutants tested were agglutinated but differences were noticed: PMV6089 was much more rapidly agglutinated than CFBP1430, while the other mutants were more slowly agglutinated. This could be related to a modification of the quantity and/or the quality of the EPS produced by the mutants. Modified EPS, altered in its chemical and/or physical properties might thus hamper the accessibility to somatic-O antigenic sites and slow down the reaction in the agglutination test. This is consistent with the observed fast agglutination of PMV6089, whose cells are not protected by EPS. Among the Path ${ }^{-}$mutants described by Barny $e$ t al. (1990) all but two (PMV6046, PMV6073) were slowly agglutinated like most of the mutants described in this paper. PMV6046 and PMV6073, in contrast, were never agglutinated in the conditions described here, agglutination only being observed from 3 -d-old cultures; these particular mutants, which most probably map in the same gene, are currently under study.

The population levels of the mutants able to multiply in the host plant never reached the level of the initial inoculum $\left(3 \times 10^{6}\right.$ c.f.u. per plant $)$, except for the Rvi mutants, while in the same time period the fully pathogenic parental strain reached about $5 \times 10^{7}$ c.f.u. per plant. The other mutants were able to survive only at a low population level, but could not multiply in the host plant. This ability to survive and/or to multiply in the host plant appeared to be linked with EPS production, since only the EPS $^{-}$PMV6089 rapidly decreased to an undetectable level. Norelli et al. (1990) reported similar observations with two EPS ${ }^{-}$mutants of E. amylovora, and so did Ayers et al. (1979) with a naturally acapsular strain of $E$. amylovora. All EPS-producing mutants, even those exhibiting a low PCC, were able to survive in the host plant. It seems therefore that (i) the presence of EPS is a requisite to ensure the survival of bacteria, and (ii) a low PCC is sufficient to allow such survival. The question of how much EPS and what kind of EPS (capsule and/or slime) is required for bacterial survival in the host plant remains open.

Each of the three classes of mutants defined here ( $\mathrm{Hrp}^{-}$, Dsp-, $\mathrm{Rvi}^{-}$) includes strains which are modified in their PCC as well as strains with a normal PCC. Insertions in several $b r p$ or $d s p$ genes appear to affect the PCC and the agglutinating properties of the mutants. Thus, mutations in the $b r p-d s p$ cluster might modify EPS production. More studies are needed to correlate a modified PCC with mutations in particular genes before investigating the nature of the changes in EPS (quality and/or quantity) reported in this work.

Assuming that avirulent strains of E. amylovora, when able to multiply in planta, might be of interest in biological control against fire blight, the ability of our $\mathrm{Path}^{-}$mutants to protect apple seedlings against infection by a virulent challenger strain was tested. In our conditions all $\mathrm{Path}^{-}$ mutants described in this paper failed to protect apple seedlings, in contrast with our positive check CFBP1376 (a naturally avirulent isolate), which had a high protective ability (data not shown). However, among the $\mathrm{Path}^{-}$ mutants described by Barny et al. (1990) we found three which exhibited the ability to protect (Tharaud et al., 
1992). The transposon insertions in the chromosome of these three mutants might be located in the same transcription unit in the brp genes cluster.

Our results are consistent with the current hypothesis on the role of brp genes in plant-pathogenic bacteria. Some brp genes are clearly regulatory, responding to plant signals to induce transcription of several other $b r p$ genes (Clarke et al., 1992; Genin et al., 1992). Other brp genes code for the synthesis and export of plant and animal pathogenicity factors (Clarke et al., 1992; Gough et al., 1992). Experiments are in progress aimed at understanding the interactions between avirulent mutants, virulent strains, and the host plant.

\section{ACKNOWLEDGEMENTS}

This work was supported in part by grants from EPR Pays de la Loire and DGER of French Ministry of Agriculture. We thank M.-A. Barny for her critical review of this manuscript. We are grateful to E. Schoonejans for providing LPS-specific bacteriophages. We thank R. Chartier and M. Thomas for helpful technical assistance, and $\mathrm{M}$. Travers for typing of the manuscript.

\section{REFERENCES}

Allen, L. N. \& Hanson, R. S. (1984). Construction of broad-hostrange cosmid cloning vectors: identification of genes necessary for growth of Methylobacterium organophilum on methanol. $J$ Bacteriol 161, 955962 .

Ayers, A. R., Ayers, S. B. \& Goodman, R. N. (1979). Extracellular polysaccharide of Erwinia amylovora: a correlation with virulence. Appl Environ Microbiol 38, 659-666.

Barny, M.-A., Guinebretière, M.-H., Marcais, B., Coissac, E., Paulin, J.-P. \& Laurent, J. (1990). Cloning of a large gene cluster involved in Erwinia amylovora CFBP1430 virulence. Mol Microbiol 4, 777-786.

Bauer, D. W. \& Beer, S. V. (1991). Further characterization of an brp gene cluster of Erwinia amylovora. Mol Plant-Microbe Interact 4, 493-499.

Belleman, P. \& Geider, K. (1992). Localization of transposon insertions in pathogenicity mutants of Erwinia amylovora and their biochemical characterization. J Gen Microbiol 138, 931-940.

Bennett, R. A. (1980). Evidence for two virulence determinants in the fire blight pathogen Erwinia amylovora. J Gen Microbiol 116, 351-356.

Bennett, R. A. \& Billing, E. (1978). Capsulation and virulence in Erwinia amylovora. Ann of Appl Biol 89, 41-45.

Bernhard, F., Coplin, D. L. \& Geider, K. (1993). A gene cluster for amylovoran synthesis in Erwinia amylovora: characterization and relationship to cps genes in Erwinia stewartii. Mol \& Gen Genet 239, $158-168$.

Billing, E. (1984). Studies on avirulent strains of Erwinia amylovora. Acta Hortic 151, 249-253.

Boucher, C., Van Gijsegem, F., Barberis, P., Arlat, M. \& Zischek, C. (1987). Pseudomonas solanacearum genes controlling both pathogenicity on tomato and hypersensitivity on tobacco are clustered. $j$ Bacteriol 169, 5626-5632.

Clarke, H. R. G., Leigh, J. A. \& Douglas, C. J. (1992). Molecular: signals in the interactions between plants and microbes. Cell 71, 191-199.

Coplin, D. L. \& Cook, D. (1990). Molecular genetics of extracellulat polysaccharide biosynthesis in vascular phytopathogenic bacteria. Mol Plant-Microbe interact 3, 271-279.

Duguid, J.P. (1951). The demonstration of bacterial capsule and slime. J Pathol Bacteriol 63, 673-685.

Expert, D. \& Toussaint, A. (1985). Bacteriocin-resistant mutants of Erwinia chrysantemi: possible involvement of iron acquisition in phytopathogenicity. J Bacteriol 163, 221-227.

Falkenstein, H., Bellemann, P., Walter, S., Zeller, W. \& Geider, K. (1988). Identification of Erwinia amylovora, the fire blight pathogen, by colony hybridization with DNA from plasmid pEA29. Appl Environ Microbiol 54, 2798-2802.

Falkenstein, H., Zeller, W. \& Geider, K. (1989). The 29 kb plasmid, common in strains of Erwinia amylovora, modulates development of fireblight symptoms. J Gen Microbiol 135, 2643-2650.

Genin, S., Gough, C. L., Zischek, C. \& Boucher, C. (1992). Evidence that the $b r p \mathrm{~B}$ gene encodes a positive regulator of pathogenicity genes from Pseudomonas solanacearum. Mol Microbiol 6, 3065-3076.

Gilleland, H. E., Jr (1977). Ultrastructural alteration of the outer membrane of Pseudomonas aeruginosa associated with resistance to polymyxin B and to EDTA. In Microbiology-1977, pp. 145-150. Edited by D. Schlessinger. Washington, DC: American Society for Microbiology.

Gough, C. L., Genin, S., Zischek, C. \& Boucher, C. A. (1992). hrp genes of Pseudomonas solanacearum are homologous to pathogenicity determinants of animal pathogenic bacteria and are conserved among plant pathogenic bacteria. Mol Plant-Microbe Interact 5, 384-389.

Hitchcock, P. J. \& Brown, T. M. (1983). Morphological heterogeneity among Salmonella lipopolysaccharide chemotypes in silverstained polyacrylamide gels. J Bacteriol 154, 269-277.

Huang, H.-C., Hutcheson, S. V. \& Collmer, A. (1991). Characterization of the brp cluster from Pseudomonas syringae pv. syringae 61 and TnphoA tagging of genes encoding exported or membranespanning Hrp proteins. Mol Plant-Microbe Interact 4, 469-476.

King, E. O., Ward, M. K. \& Raney, D. E. (1954). Two simple media for the demonstration of pyocyanin and fuorescein. $J$ Lab Clin Med 44, 301 307

Klotz, L. \& Zimm, B. H. (1972). Size of DNA determined by viscoelastic measurements: results on bacteriophages, Bacillus subtilis and Escherichia coli. J Mol Microbiol 72, 779-800.

Laurent, J., Paulin, J.-P. \& Zucca, J. (1987). Ultrastructural study of Erwinia amylovora strains: effect of culture conditions and fixation procedures. Protoplasma 139, 1-8.

Laurent, J., Barny, M. A., Kotoujansky, A., Dufriche, P. \& Vanneste, J. L. (1989). Characterization of a ubiquitous plasmid in Erwinia amylovora. Mol Plant-Microbe Interact 2, 160-164.

Lindberg, A. A. (1973). Bacteriophage receptors. Annu Rev Microbiol 27, 205-241.

Maniatis, T., Fritsch, E. F. \& Sambrook, J. (1982). Molecular Cloning. A Laboratory Manual. Cold Spring Harbor, NY: Cold Spring Harbor Laboratory.

Miller, J. H. (1972). Experiments in Molecular Genetics. Cold Spring Harbor, NY: Cold Spring Harbor Laboratory.

Murray, N. E., Brammar, W. J. \& Murray, K. (1977). Lambdoid phages that simplify the recovery of in vitro recombinants. Mol \& Gen Genet 150, 53-61.

Nikaido, H. \& Vaara, M. (1985). Molecular basis of bacterial outer membrane permeability. Microbiol Rev 49, 1-32.

Norelli, J. L., Gilbert, M. T., Aldwinckle, H. S., Zumoff, C. H. \& Beer, S. V. (1990). Population dynamics of non pathogenic mutants of Erwinia amylovora in apple host-tissue. Acta Hortic 273, 239-240. 
Paulin, J.-P. \& Samson, R. (1973). Le feu bactérien en France. II. Caractères des souches d'Erwinia amylovora (Burrill) Winslow et al., 1920, isolées du foyer franco-belge. Ann Pbytopathol 5, 389-397.

Paulin, J. P. \& Duron, M. (1986). Identification des souches pathogènes d'Erwinia amylovora par inoculation de cals de racine de Malus domestica, cv. 'Golden Delicious'. Agronomie 6, 869-872.

Résibois, A., Colet, M., Faelen, M., Schoonejans, E. \& Toussaint, A. (1984). Phi EC2, a new generalized transducing phage of Erwinia chrysanthemi. Virology 137, 102-112.

Roberts, I. S. \& Coleman, M. J. (1991). The virulence of Erwinia amylovora: molecular genetic perspectives. J Gen Micrabiol 137, 1453-1457.

Samson, R. (1972). Hétérogénéité des antigènes thermostables de surface chez Erwinia amylovora. Ann Pbytopatbol 4, 157-163.

Schmieger, H. \& Backhaus, H. (1973). The origin of DNA in transducing particles in P22-mutants with increased transductionfrequencies (HT-mutants). Mol Gen Genet 120, 181-190.

Schoonejans, E., Expert, D. \& Toussaint, A. (1987). Characterization and virulence properties of Erwinia cbrysantemi lipopolysaccharide-defective, Phi EC2-resistant mutants. J Bacteriol 169, 4011-4017.

Sijam, K., Karr, A. L. \& Goodman, R. N. (1983). Comparison of the extracellular polysaccharides produced by Erwinia amylovora in apple tissue and culture medium. Physiol Plant Pathol 22, 221-231.

Steinberger, E. M. \& Beer, S. V. (1988). Creation and comple- mentation of pathogenicity mutants of Erwinia amylovora. Mol Plant-Microbe Interact 1, 135-144.

Tharaud, M., Baudouin, E. \& Paulin, J.P. (1993). Protection against Fire Blight by avirulent strains of Erwinia amylovora: modulation of the interaction by avirulent mutants. In Proceedings of the 6th International Workshop on Fire Blight, October 1992, Athens (Greece) Acta Hortic 338, 321-327.

Vanneste, J. L., Paulin, J.-P. \& Expert, D. (1990). Bacteriophage Mu as a genetic tool to study Erwinia amylovora pathogenicity and hypersensitive reaction on tobacco. J Bacteriol 172, 932-941.

Walters, K., Maroofi, A., Hitchin, E. \& Mansfield, J. (1990). Gene for pathogenicity and ability to cause the hypersensitive reaction cloned from Erwinia amylovora. Physiol Mol Plant Pathol 36, 509-521.

Wei, Z.-M., Sneath, B. J. \& Beer, S. V. (1992a). Expression of Erwinia amylovora hrp genes in response to environmental stimuli. $J$ Bacteriol 174, 1875-1882.

Wei, Z.-M., Laby, R. J., Zumoff, C. H., Bauer, D. W., He, S. Y., Collmer, A. \& Beer, S. V. (1992b). Harpin, elicitor of the hypersensitive response produced by the plant pathogen Erwinia amylovora. Science $\mathbf{2 5 7}, 85-88$.

Wilkinson, R. G., Gemski, T., Jr \& Stocker, B. A. D, (1972). Nonsmooth mutants of Salmonella typhimurium: differentiation by phage sensitivity and genetic mapping. J Gen Microbiol 70, 527-553.

Received 12 July 1993; revised 22 September 1993; accepted 27 September 1993. 